\title{
Superoxide Production by Digitonin-Stimulated Guinea Pig Granulocytes
}

\author{
THE EFFECTS OF $N$-ETHYL MALEIMIDE, DIVALENT CATIONS, \\ AND GLYCOLYTIC AND MITOCHONDRIAL INHIBITORS \\ ON THE ACTIVATION OF THE SUPEROXIDE GENERATING SYSTEM
}

\author{
Harvey J. Cohen and Margaret E. Chovaniec, Division of Hematology-Oncology, \\ Children's Hospital Medical Center, and the Department of Pediatrics, Harvard \\ Medical School, Boston, Massachusetts 02115
}

A B S T RACT $N$-ethylmaleimide, divalent cations, ethylene glycol bis ( $\beta$ aminoethyl ether) $N, N, N^{\prime}, N^{\prime}$,-tetraacetate, 2-deoxyglucose, cyanide, and dinitrophenol were examined for their effect on the ability of guinea pig granulocytes to generate superoxide $\left(\mathrm{O}_{2}^{-}\right)$when stimulated by digitonin. $N$-ethylmaleimide $(1 \mathrm{mM})$ inhibits only when added before complete activation of the $\mathrm{O}_{2}^{-}$generating system, and at lower concentrations (0.05-0.2 $\mathrm{mM}$ ) slows the activation process. $\mathrm{Ca}^{++}$is required for maximum $\mathrm{O}_{2}^{-}$generation, and $\mathrm{Mg}^{++} \mathrm{de}-$ creases the amount of $\mathrm{Ca}^{++}$required. Ethylene glycol bis ( $\beta$ aminoethyl ether) $N, N, N^{\prime}, N^{\prime}$,-tetraacetate (10 $\mathrm{mM}$ ) inhibits only if added before complete activation. Incubation of cells in 2-DOG causes a time- and concentration-dependent inhibition of $\mathrm{O}_{2}^{-}$generation. It also increases the time required for activation of this system. Cyanide and dinitrophenol increase the rate of $\mathrm{O}_{2}^{-}$production. However, when these compounds are added to cells whose $\mathrm{O}_{2}^{-}$production is partially inhibited by incubation in 2-deoxyglucose, complete inhibition results. If cyanide or dinitrophenol is added after activation of 2-deoxyglucose-treated cells, no further inhibition occurs. On the basis of the above results, we conclude that the activation of the $\mathrm{O}_{2}^{-}$generating system is $N$-ethylmaleimide sensitive, $\mathrm{Ca}^{++}$dependent, and energy requiring, but that the activity of the enzyme system in the cell is not.

A preliminary report was presented at the 19th Annual Meeting of the American Society of Hematology, Boston, Mass., 6-10 December 1976.

Dr. Cohen is a Charles A. Janeway, Jr. Scholar and a recipient of an American Cancer Society Junior Faculty Clinical Fellowship.

Received for publication 7 July 1977 and in revised form 12 December 1977.

\section{INTRODUCTION}

A continuous assay for superoxide $\left(\mathrm{O}_{2}^{-}\right)^{1}$ production by digitonin-stimulated guinea pig granulocytes allows monitoring of both the rate of generation of this metabolite and the activation of the system responsible for its production (1). The ability of phagocytic cells to generate $\mathrm{O}_{2}^{-}$is dependent upon both of these processes. Factors which are known to affect the oxidative burst accompanying phagocytosis may do so by altering the activation process, the generating system, or both. This paper describes the effect on $\mathrm{O}_{2}^{-}$generation by $\mathrm{N}$-ethylmaleimide (NEM), divalent cations, and substances that alter cellular energy metabolism.

\section{METHODS}

Reagents were used as previously described (1). NEM, dinitrophenol (DNP), and 2-deoxyglucose (2-DOG) were purchased from Sigma Chemical Co., St. Louis, Mo. The calcium ionophore A23187 was obtained from Eli, Lilly \& Co., Indianapolis, Ind., Oil red O from Allied Chemical Corp., Morristown, N. J., and phthalate oil from Matheson, Coleman and Bell Co., East Rutherford, N. J.

Spectrophotometric assays were performed in a doublebeam Perkin-Elmer model 571 spectrophotometer (PerkinElmer Corp., Norwalk, Conn.) equipped with an electronically thermostatted cell compartment. Unless otherwise stated, all reactions were followed at $37^{\circ} \mathrm{C}$.

Granulocytes were harvested from the peritoneal cavity of casein-injected guinea pigs by a previously described procedure (2) and, except where noted, were suspended in Krebs-

\footnotetext{
${ }^{1}$ Abbreviations used in this paper: DNP, dinitrophenol; 2-DOG, 2-deoxyglucose; EGTA, ethylene glycol bis ( $\beta$ aminoethyl ether) $N, N, N^{\prime}, N^{\prime}$-tetraacetate; KRP, Krebs-Ringer phosphate; MPO, myeloperoxidase; NEM, $\mathrm{N}$-ethylmaleimide; $\mathrm{O}_{2}^{-}$, superoxide.
} 
Ringer phosphate (KRP) at a final concentration of $5 \times 10^{7}$ cells $/ \mathrm{ml}$

Rabbit pulmonary alveolar macrophages were obtained from Freund's adjuvant-treated New Zealand white rabbits by a previously described procedure (3).

$\mathrm{O}_{2}^{-}$production by phagocytic cells. $0.05 \mathrm{ml}$ cytochrome $c(50 \mathrm{nmol}), 0.04 \mathrm{ml}$ digitonin $(10 \mu \mathrm{g})$, and $0.86 \mathrm{ml} \mathrm{KRP}$ were mixed in a 1-ml cuvette and placed in the sample compartment of the spectrophotometer. $0.05 \mathrm{ml}$ cytochrome $c$ (50 $\mathrm{nmol}), 0.04 \mathrm{ml}$ digitonin $(10 \mu \mathrm{g}), 0.01 \mathrm{ml}$ superoxide dismutase $(10 \mu \mathrm{g})$, and $0.85 \mathrm{ml} \mathrm{KRP}$ were mixed in a $1-\mathrm{ml}$ cuvette and placed in the reference sample compartment. $0.05 \mathrm{ml}$ of phagocytic cells $\left(2.5 \times 10^{6}\right)$ were then added to each cuvette and the absorbance change at $550 \mathrm{~nm}$ was recorded. As previously described (1), immediately after mixing there is a period in which no observable change in absorbance occurs followed by an increasing rate of absorbance change until a linear rate occurs. The rate of $\mathrm{O}_{2}^{-}$production is taken from this linear increase in absorbance. The activation period is the time between the mixing of cells with digitonin and the onset of the linear rate. The lag time is defined as the time that corresponds to where an extrapolation of this linear rate intersects the base line. Identical results are obtained if digitonin is added last. In all assays any additional reagents were added to both the sample and reference compartments. All results reported, unless otherwise stated, are the average of two determinations which differ by less than $10 \%$ from each other.

Granulocyte ATP content. Granulocytes at about 4.5 $\times 10^{7} / \mathrm{ml}$ in KRP were used to measure ATP content. $1-\mathrm{ml}$ samples were mixed with $0.5 \mathrm{ml} 12 \%$ perchloric acid to precipitate the protein. The resulting supernates were mixed with $0.25 \mathrm{ml} 4 \mathrm{M} \mathrm{HCO}_{3}$ to neutralize and precipitate $\mathrm{KClO}_{4} .0 .4 \mathrm{ml}$ of each neutralized supernate was added to $1-\mathrm{ml}$ reaction mix containing Tris $-\mathrm{HCl}(10 \mathrm{mM}) \mathrm{pH} 8.0, \mathrm{MgCl}_{2}(2 \mathrm{mM})$, glucose $(10 \mathrm{mM})$, NADP $(0.3 \mathrm{mM})$, hexokinase (1 IU), and glucose-6phosphate dehydrogenase (1 IU) as previously described (4). After incubating at room temperature for $60 \mathrm{~min}$, the absorbances at $340 \mathrm{~nm}$ were recorded and compared to values obtained with 0.4-ml samples of known ATP concentration. All results reported are the average of three samples.

Ingestion of particles by phagocytes. Ingestion of opsonized particles by granulocytes was studied by the method of Stossel et al. (5) with endotoxin-coated phthalate oil containing Oil red $\mathrm{O}$ dye and opsonized with fresh guinea pig serum. Assay mixtures contained phagocytic cells at $2 \times 10^{7}$ $\mathrm{ml}$ and opsonized particles $(6 \mathrm{mg}$ endotoxin/ml) in KRP with and without the additions noted. At various times from 0 to 5 min, 1-ml samples were placed in 10-ml ice-cold normal saline containing $1 \mathrm{mM} \mathrm{NEM}$. The cells were centrifuged, then washed three times in the same cold saline solution; the dye was extracted into dioxane, and absorbance at $520 \mathrm{~nm}$ recorded. All results are the average of two determinations.

\section{RESULTS}

Effect of NEM on $\mathrm{O}_{2}^{-}$generation by guinea pig granulocytes. NEM interferes with oxidative metabolism in phagocytic cells $(6,7)$. Complete inhibition of digitonin-induced $\mathrm{O}_{2}^{-}$production by granulocytes occurs at $1 \mathrm{mM}$ NEM.

Because the production of $\mathrm{O}_{2}^{-}$by granulocytes is a result of two phenomena: $(a)$ the activation of an $\mathrm{O}_{2}^{-}$ generating system and $(b)$ the activity of this enzyme system, the results of the above experiment could be the result of an effect of NEM on the activation or the

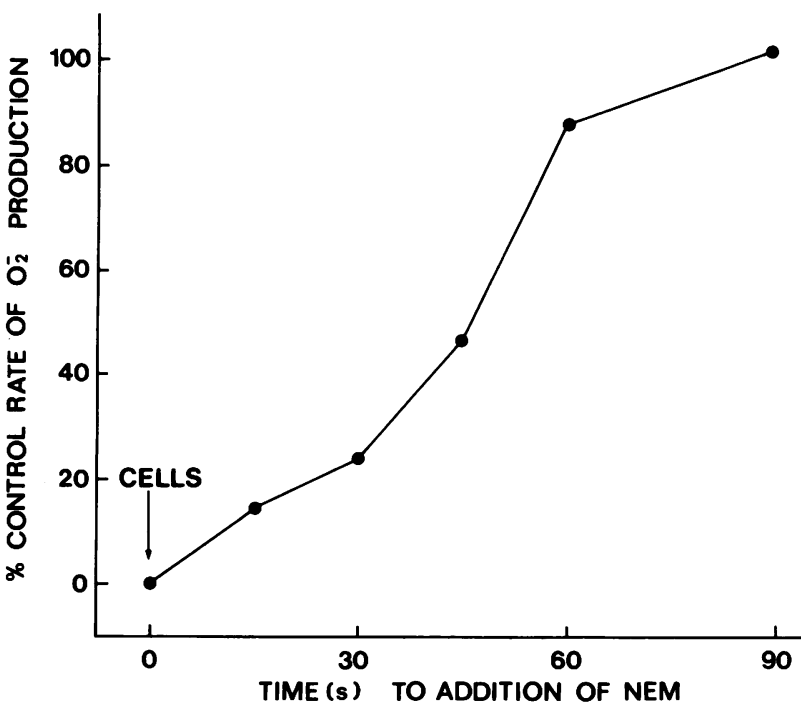

FIGURE 1 Effect of time to addition of $\mathrm{NEM}$ on $\mathrm{O}_{2}^{-}$generation. NEM ( $1 \mathrm{mM})$ was added to the assay mixture just before or at various times after the addition of cells, and the final linear rates of $\mathrm{O}_{2}^{-}$production were recorded.

enzyme system itself. To determine which process is affected, NEM was added at various times both before and after the addition of cells. As can be seen in Fig. 1, when $1 \mathrm{mM}$ is added at the same time as the granulocytes, complete inhibition of $\mathrm{O}_{2}^{-}$generation occurs. However, as the interval between the addition of cells and NEM increases, there is progressively less inhibition by NEM. If NEM is added $90 \mathrm{~s}$ after the cells, there is no inhibition of subsequent $\mathrm{O}_{2}^{-}$production. This corresponds to the time required for complete activation of the $\mathrm{O}_{2}^{-}$generating system (1).

We examined the effect of NEM on the lag time for $\mathrm{O}_{2}^{-}$generation. Fig. 2 shows that at concentrations of $\mathrm{NEM}$ between 0.05 and $0.2 \mathrm{mM}$, there is both increasing inhibition of the final linear rate of $\mathrm{O}_{2}^{-}$generation and an increase in the lag time. We conclude that NEM prevents complete activation of the generating system and slows down the rate of its activation.

Effect of NEM on ingestion. One of the criteria used to distinguish ingestion from attachment has been inhibition of the former by NEM (5). We investigated the effect of the time of addition of NEM on ingestion of opsonized particles by guinea pig granulocytes. Fig. 3 shows that if NEM is added at zero time there is no ingestion of particles. When added at various times after the onset of ingestion, NEM prevents any further ingestion of particles. These results indicate that whereas ongoing $\mathrm{O}_{2}^{-}$generation is insensitive to $\mathrm{NEM}$, ingestion is sensitive to NEM at all times. A similar pattern of inhibition of ingestion by NEM was obtained with rabbit pulmonary alveolar macrophages as the phagocytic cells. 


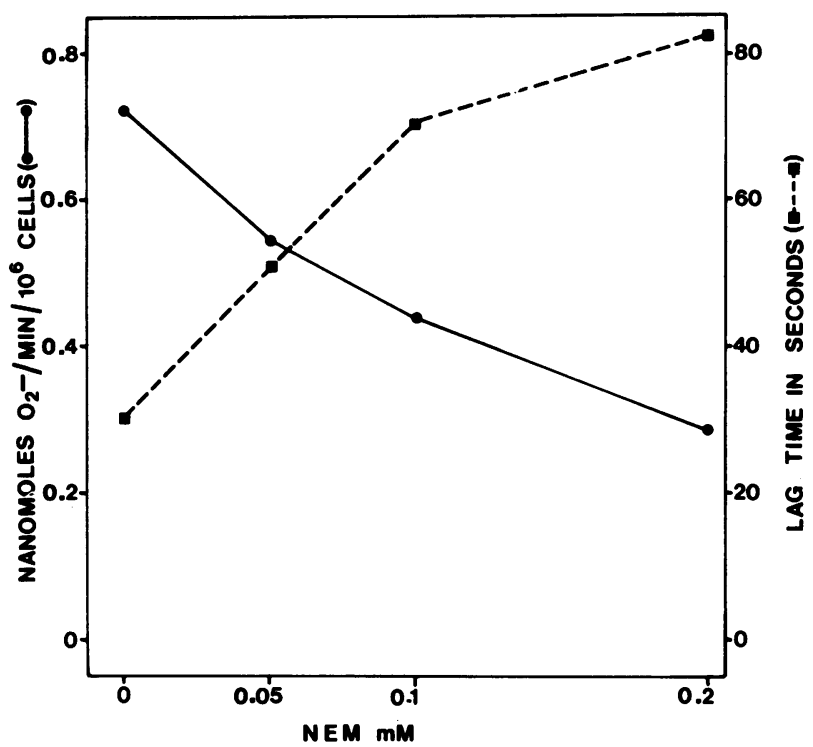

FIGURE 2 The effect of NEM on the rate of activation of the $\mathrm{O}_{2}^{-}$generating system. $\mathrm{NEM}$, at the concentrations noted, was added to the assay mixture before the addition of cells; the final rate of $\mathrm{O}_{2}^{-}$generation $(\Theta)$ and the lag time ( $(\mathbf{D})$ are plotted.

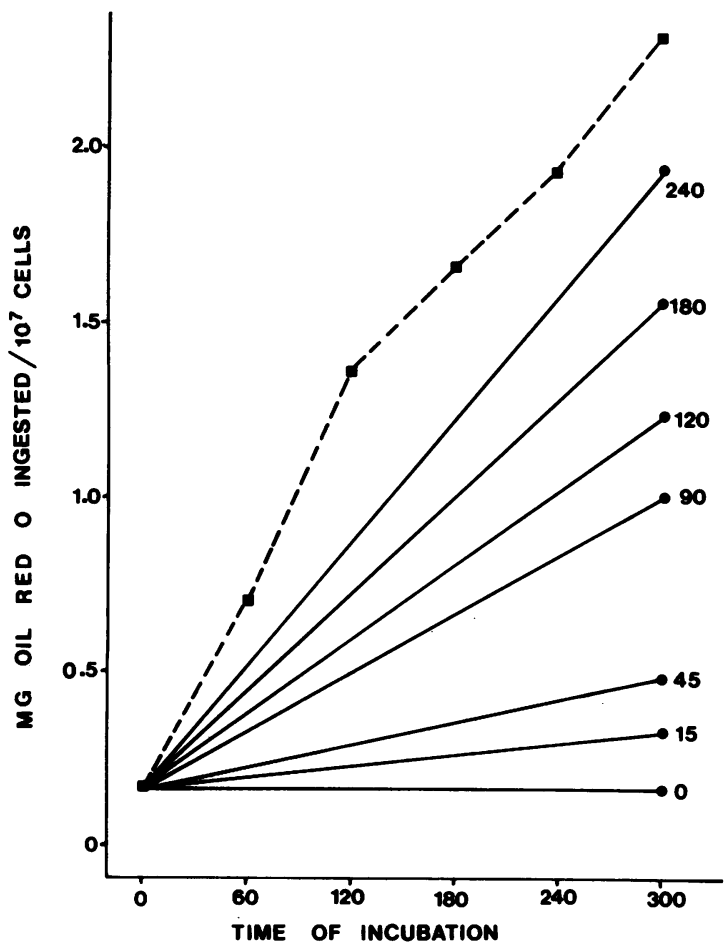

FIGURE 3 The effect of NEM on ingestion of particles. Ingestion assays were performed as described in Methods. At various times the reaction was stopped by the addition of icecold KRP containing $1 \mathrm{mM}$ NEM ( $\square$ ). To other samples, at the times noted, $1 \mathrm{mM}$ NEM was added and the assays continued for a total of 5 min before stopping with ice-cold KRP containing $1 \mathrm{mM}$ NEM (O). The times listed in this figure are in seconds.
Effect of divalent cations on $\mathrm{O}_{2}^{-}$generation. Divalent cations, $\mathrm{Ca}^{++}(1.0 \mathrm{mM})$ and $\mathrm{Mg}^{++}(1.5 \mathrm{mM})$, are part of KRP buffer and are involved in the phagocytic process $(5,8)$. We examined the effects of each on $\mathrm{O}_{2}^{-}$ generation by granulocytes. The absence of either $\mathrm{Ca}^{++}$ or $\mathrm{Mg}^{++}$causes a significant decrease in $\mathrm{O}_{2}^{-}$generation $\left(\mathrm{Ca}^{++}>\mathrm{Mg}^{++}\right)$. In the absence of both divalent cation no $\mathrm{O}_{2}^{-}$production occurs. To study the interrelationships of the two divalent cations, the rate of $\mathrm{O}_{2}^{-}$generation was examined as a function of $\mathrm{Ca}^{++}$concentration in the presence and absence of $1.5 \mathrm{mM} \mathrm{Mg}^{++}$. The results are shown in Fig. 4. In the absence of $\mathrm{Ca}^{++}$very little $\mathrm{O}_{2}^{-}$generation occurs. As the $\mathrm{Ca}^{++}$concentration increases more $\mathrm{O}_{2}^{-}$is generated. In the presence of $\mathrm{Mg}^{++}$maximum $\mathrm{O}_{2}^{-}$generation occurs at $0.5 \mathrm{mM} \mathrm{Ca}^{++}$. In the absence of $\mathrm{Mg}^{++}$the same maximum rate is obtained but requires $2.0 \mathrm{mM} \mathrm{Ca}^{++}$. Only $\mathrm{Ca}^{++}$is necessary for $\mathrm{O}_{2}^{-}$generation, and $\mathrm{Mg}^{++}$acts by decreasing the concentration of $\mathrm{Ca}^{++}$required for maximum rates.

To examine whether the effect of $\mathrm{Ca}^{++}$is on the activation process or the enzyme activity, the $\mathrm{Ca}^{++}$-chelator ethylene glycol bis ( $\beta$ aminoethyl ether) $N, N, N^{\prime}, N^{\prime}$ tetraacetate (EGTA) was used. Table I shows the effects of $10 \mathrm{mM}$ EGTA on $\mathrm{O}_{2}^{-}$generation. EGTA added before the addition of cells, inhibits the rate by $75 \%$, but EGTA added 3 min after the cells produces no inhibition. KRP without $\mathrm{Ca}^{++}$supports only a small amount of $\mathrm{O}_{2}^{-}$production.

The possible role of $\mathrm{Ca}^{++}$transport in the activation

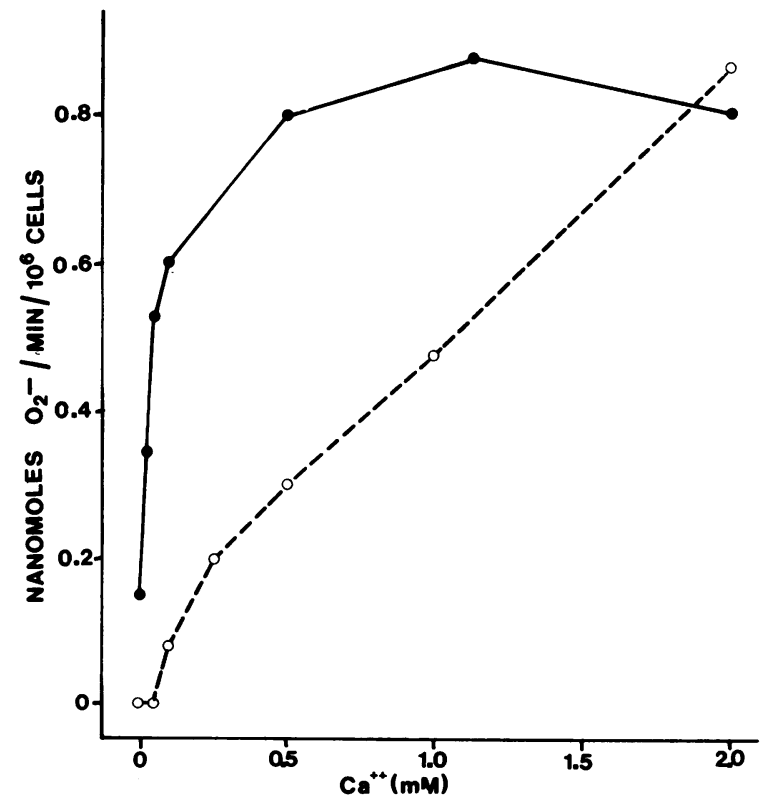

FIGURE 4 The effect of $\mathrm{Ca}^{++}$on digitonin-induced $\mathrm{O}_{2}^{-}$production by granulocytes. $\mathrm{Ca}^{++}$, at the concentrations noted on the abscissa, was added to standard assays for $\mathrm{O}_{2}^{-}$production

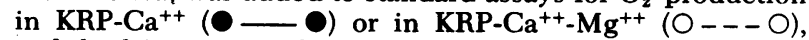
and the linear rates of $\mathrm{O}_{2}^{-}$produced were recorded. 
TABLE I

Effect of EGTA on $\mathrm{O}_{2}^{-}$Production by Granulocytes

\begin{tabular}{lccc}
\hline & Additions & Time of addition & $\mathrm{O}_{2}^{-}$production \\
\cline { 3 - 4 } & & & $\begin{array}{c}n m o l ~ O_{2}^{-} / \mathrm{min} / \\
10^{8} \text { cells }\end{array}$ \\
$\mathrm{KRP}$ & - & - & 1.17 \\
$\mathrm{KRP}$ & $10 \mathrm{mM}$ EGTA & zero & 0.30 \\
$\mathrm{KRP}$ & $10 \mathrm{mM}$ EGTA & $3 \mathrm{~min}$ & 1.16 \\
$\mathrm{KRP}-\mathrm{Ca}^{++}$ & - & - & 0.20 \\
\hline
\end{tabular}

Digitonin-stimulated $\mathrm{O}_{2}^{-}$production was monitored in the above buffers with the additions as noted. Except where indicated, each solution contains $1.0 \mathrm{mM} \mathrm{Ca}^{++}$and 1.5 $\mathrm{mM} \mathbf{M g}^{++}$.

process was studied by examining the effects of the $\mathrm{Ca}^{++}$-ionophore, $\mathrm{A} 23187$, on the lag time and sensitivity to NEM. Although the ionophore in the absence of digitonin caused a small amount of $\mathrm{O}_{2}^{-}$production by granulocytes, the lag time for digitonin-stimulated $\mathrm{O}_{2}^{-}$ production was unaffected by the ionophore. In addition, the time-dependent effect of $\mathrm{NEM}$ on $\mathrm{O}_{2}^{-}$generation was not altered by the presence of $\mathrm{A} 23187$. These results indicate that $\mathrm{Ca}^{++}$is necessary for the activation of the $\mathrm{O}_{2}^{-}$generating enzyme, not for its continued activity, and that $\mathrm{Ca}^{++}$transport, if it occurs, does not appear to be a rate limiting step in this activation.

The effect of energy metabolism on $\mathrm{O}_{2}^{-}$generation. Both ingestion and oxidative metabolism are inhibited by inhibitors of glycolysis (6) and either unaffected (ingestion) (5) or stimulated (oxidative metabolism) (9) by inhibitors of mitochondrial energy formation. Fig. 5 shows the effect of the glycolytic inhibitor, 2-deoxyglucose (2-DOG), on $\mathrm{O}_{2}^{-}$generation and ATP content. This experiment was performed by incubating granulocytes at $4.8 \times 10^{7} / \mathrm{ml}$ in KRP containing $10 \mathrm{mM}$ 2-DOG. At various times samples were removed and both ATP content and the ability of the cells to generate $\mathrm{O}_{2}^{-}$in the presence of digitonin were measured. There is a direct relationship between the level of ATP in the cell and the rate of $\mathrm{O}_{2}^{-}$production. Control cells incubated for up to $60 \mathrm{~min}$ showed no change in either their ability to generate $\mathrm{O}_{2}^{-}$or in ATP content. Fig. 6 shows the ability of glucose to prevent both the 2-DOG-induced loss of ATP and the inhibition of $\mathrm{O}_{2}^{-}$generation. Mannose $(10 \mathrm{mM})$ could also partially prevent the loss of both ATP and $\mathrm{O}_{2}^{-}$generating ability by 2-DOG (10 $\mathrm{mM}$ ). Galactose, fructose, dihydroxyacetone, adenosine, inosine, succinate, and pyruvate at $10-\mathrm{mM}$ concentrations were similarly tested. None of these could either prevent the 2-DOG-induced loss of ATP or the loss of $\mathrm{O}_{2}^{-}$generating ability by granulocytes. Glucose $(8 \mathrm{mM})$ by itself caused threefold stimulation of $\mathrm{O}_{2}^{-}$ production but had no effect on ATP content. Despite the marked stimulation of $\mathrm{O}_{2}^{-}$production by glucose,

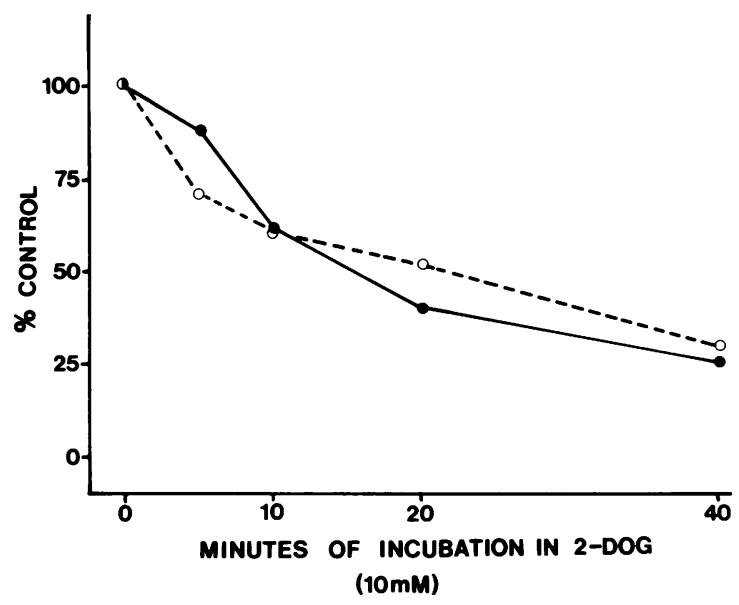

FIGURE 5 Effect of $10 \mathrm{mM}$ 2-DOG on $\mathrm{O}_{2}^{-}$generation and ATP content. $4.8 \times 10^{7}$ granulocytes $/ \mathrm{ml}$ were incubated in the presence of $10 \mathrm{mM} 2-\mathrm{DOG}$ at the times noted. Samples were removed and assayed for their ability to generate $\mathrm{O}_{2}^{-}$in the presence of digitonin and $10 \mathrm{mM}$ 2-DOG $(O)$ and ATP content (O). Results are expressed as a percentage of zero time. Cells incubated for up to $1 \mathrm{~h}$ in buffer had unaltered ability to generate $\mathrm{O}_{2}^{-}$and slight increases in ATP content.

there was no effect of glucose on the rate of activation of the $\mathrm{O}_{2}^{-}$generating system.

Fig. 7 shows that the presence of either dinitrophenol (DNP) or cyanide $\left(\mathrm{CN}^{-}\right)$in the assay mixture causes an increase in the rate of $\mathrm{O}_{2}^{-}$production. $\mathrm{CN}^{-}$consistently caused a greater increase in this rate than DNP. In another experiment the addition of the two together

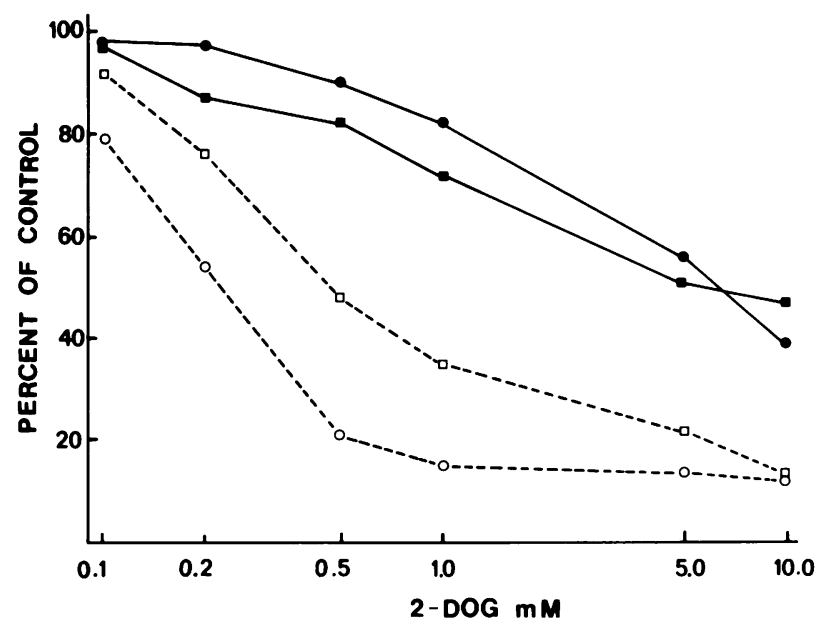

Figure 6 Effect of glucose on 2-DOG inhibition of $\mathrm{O}_{2}^{-}$generation and ATP content. Cells at $5 \times 10^{7} / \mathrm{ml}$ were incubated for $30 \mathrm{~min}$ at $37^{\circ} \mathrm{C}$ at the concentrations of 2 -DOG noted on the abscissa in the absence (open figures) and presence (closed figures) of $2 \mathrm{mM}$ glucose. After $30 \mathrm{~min}$, samples were removed for measurement of ATP content $(O, O)$ and digitonin-induced $\mathrm{O}_{2}^{-}$production in the presence of the same concentrations of 2-DOG and glucose $(\square, \square)$. Results are expressed as a percentage of the values obtained in the absence of 2 -DOG. 


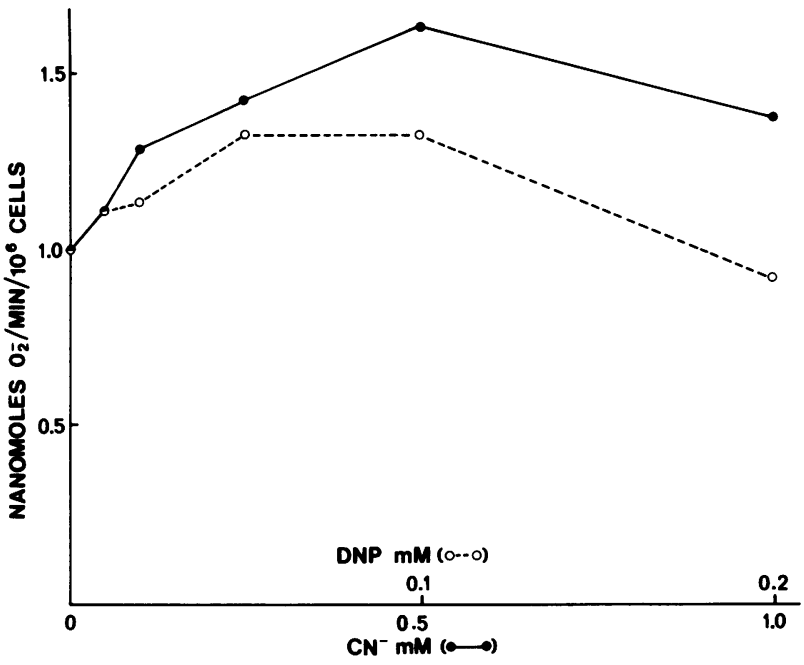

FIGURE 7 Effect of $\mathrm{CN}^{-}$and DNP on $\mathrm{O}_{2}^{-}$generation by digitonin-stimulated granulocytes. $\mathrm{CN}^{-}(\mathrm{O})$ and $\mathrm{DNP}(\mathrm{O})$ at the concentrations noted were added to a standard assay mixture before the addition of granulocytes. Final linear rates of $\mathrm{O}_{2}^{-}$ production are given as a function of the concentrations of $\mathrm{CN}^{-}$and DNP.

gave the same stimulation of $\mathrm{CN}^{-}$alone. Neither agent affected the rate of activation.

We next studied the possible interactions between the two forms of energy metabolism. Cells were incubated in the presence or absence of $10 \mathrm{mM}$ 2-DOG for $5 \mathrm{~min}$ and then aliquots were removed and assayed for digitonin-induced $\mathrm{O}_{2}^{-}$generation with and without $\mathrm{CN}^{-}$or DNP. The results are shown in Table II. $\mathrm{CN}^{-}$ and DNP stimulated $\mathrm{O}_{2}^{-}$generation in cells incubated in buffer as noted above. A 5-min incubation in $10 \mathrm{mM}$ 2-DOG inhibits $\mathrm{O}_{2}^{-}$generation by only $23 \%$. The addition of $\mathrm{CN}^{-}$or DNP to these cells results in complete inhibition of digitonin-induced $\mathrm{O}_{2}^{-}$production. This in-

TABLE II

Effects of $\mathrm{CN}^{-}$and DNP on Superoxide Production with and without Previous Incubation in 2-DOG

\begin{tabular}{|c|c|c|c|}
\hline & Additions & $\mathrm{O}_{2}^{-}$production & Control \\
\hline & & $\mathrm{nmol} \mathrm{O}_{2} / \mathrm{min} / 10^{6} \mathrm{cells}$ & $\%$ \\
\hline \multirow[t]{3}{*}{ Control } & None & 0.990 & - \\
\hline & $+\mathrm{CN}^{-}(1 \mathrm{mM})$ & 1.760 & 178 \\
\hline & $+\operatorname{DNP}(0.1 \mathrm{mM})$ & 1.396 & 141 \\
\hline \multirow{3}{*}{$\begin{array}{l}\text { 2-DOG } \\
\qquad(10 \mathrm{mM})\end{array}$} & None & 0.768 & 77 \\
\hline & $+\mathrm{CN}^{-}(1 \mathrm{mM})$ & 0 & 0 \\
\hline & $+\operatorname{DNP}(0.1 \mathrm{mM})$ & 0 & 0 \\
\hline
\end{tabular}

Granulocytes at $5 \times 10^{7} / \mathrm{ml}$ were incubated for $5 \mathrm{~min}$ in either KRP or 2-DOG and then $50 \mu \mathrm{l}$ was added to standard assay cuvettes containing the additions shown and $\mathrm{O}_{2}^{-}$production monitored. dicates a role for mitochondrial energy metabolism in addition to glycolytic energy metabolism in the generation of $\mathrm{O}_{2}^{-}$.

To determine whether the role of energy metabolism was in the activation process or the enzyme activity itself, the following experiment was performed. Granulocytes were incubated for $5 \mathrm{~min}$ in 2-DOG, and samples were removed for assay of $\mathrm{O}_{2}^{-}$production. At various times during the course of the assay, $1 \mathrm{mM} \mathrm{CN}^{-}$ was added to the assay cuvettes. The results are shown in Fig. 8. When $\mathrm{CN}^{-}$is added together with cells, almost complete inhibition of $\mathrm{O}_{2}^{-}$generation occurs. As the time between the addition of cells and $\mathrm{CN}^{-}$increases, there is progressively less inhibition. After 120 s, i.e., after complete activation occurs, the addition of $\mathrm{CN}^{-}$results in about a $30 \%$ increase in enzyme activity. This is similar to what is seen in cells not incubated with 2-DOG. These results indicate that it is the activation process that is energy dependent but not the enzyme activity itself. Similar results were obtained with DNP.

A similar experiment adding 2-DOG at various times after the addition of cells was not helpful because to inhibit $\mathrm{O}_{2}^{-}$generation incubation of the cells was required. However, evidence that 2-DOG exerts its effect during activation was obtained by examining the lag time for the activation of the $\mathrm{O}_{2}^{-}$generating enzyme. Fig. 9 shows the effect of incubation of granulocytes with varying concentrations of $2-D O G$ on both the rate of $\mathrm{O}_{2}^{-}$generation and the lag time. Not only is the final rate obtained affected by incubation of cells with 2-DOG, but the lag time is increased with increasing

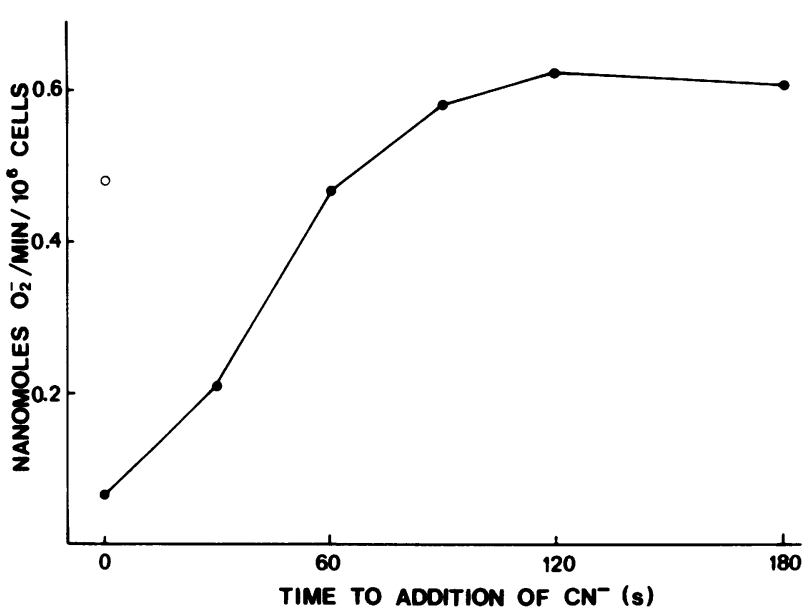

FIGURE 8 Effect of time of addition of $\mathrm{CN}^{-}$to 2-DOG-treated cells on $\mathrm{O}_{2}^{-}$production. Cells were incubated with $10 \mathrm{mM}$ 2-DOG for $5 \mathrm{~min}$ at $37^{\circ} \mathrm{C}$, then placed on ice. Assays for the ability of the cells to generate $\mathrm{O}_{2}^{-}$were then performed and at the times noted during the course of the assay, $1 \mathrm{mM} \mathrm{CN}^{-}$ was added (O). The open circle represents the rate in the absence of $\mathrm{CN}^{-}$. 


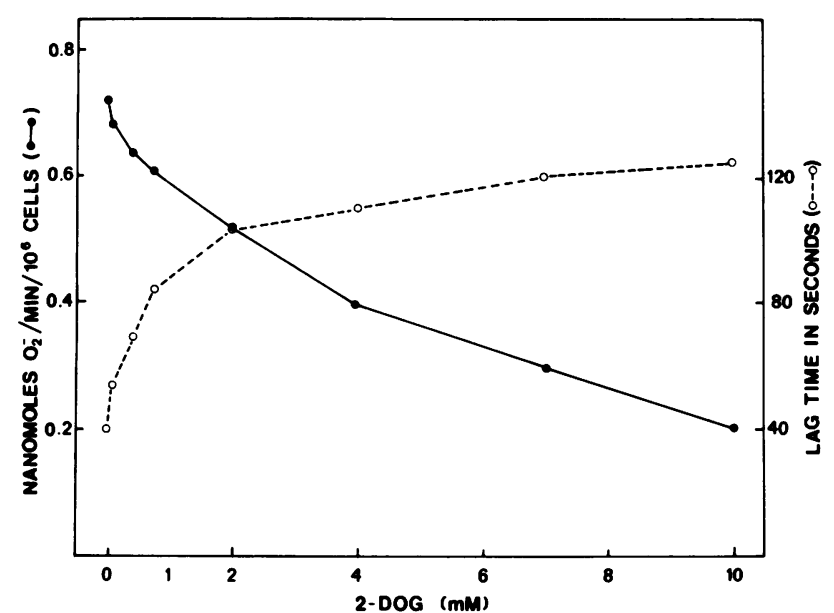

FIGURE 9 Effect of 2-DOG on the activation of the $\mathrm{O}_{2}^{-}$generating system. Cells at $5 \times 10^{7} / \mathrm{ml}$ were incubated for $15 \mathrm{~min}$ in the concentrations of 2-DOG as noted on the abscissa. 50 $\mu \mathrm{l}$ of each sample was added to standard assays for $\mathrm{O}_{2}^{-}$production, and the linear rates $(\Theta)$ and lag times $(O)$ were recorded.

amounts of 2-DOG. This indicates an effect of 2-DOG on the activation process.

Effect of $\mathrm{CN}^{-}$and 2-DOG on ATP levels. ATP concentrations were measured in granulocytes incubated in 2-DOG with and without $\mathrm{CN}^{-}$and with and without digitonin. Table III shows that whereas incubation in 2-DOG resulted in a marked decrease in cellular ATP, the addition of $\mathrm{CN}^{-}$in the presence of 2-DOG had very little further effect on ATP levels. The presence of digitonin caused no depletion of ATP content of these cells.

Effect of $\mathrm{CN}^{-}$on $\mathrm{O}_{2}^{-}$generation by rabbit pulmonary alveolar macrophages. We measured $\mathrm{O}_{2}^{-}$generation in rabbit pulmonary alveolar macrophages. These cells, unlike other phagocytic cells, derive their ATP from

TABLE III

Effect of 2-DOG, $\mathrm{CN}^{-}$, and Digitonin on ATP Content of Granulocytes

\begin{tabular}{lc}
\hline \multicolumn{1}{c}{ Additions } & ATP content \\
\hline & $n$ nmol ATP/10 cells \\
& $27.4 \pm 0.9$ \\
$10 \mathrm{mM}$ 2-DOG & $8.4 \pm 0.6$ \\
$10 \mu \mathrm{g} / \mathrm{ml}$ digitonin & $27.8 \pm 0.1$ \\
$10 \mathrm{mM}$ 2-DOG $+10 \mu \mathrm{g} / \mathrm{ml} \mathrm{digitonin}^{-}$ & $7.6 \pm 0.6$ \\
$10 \mathrm{mM}$ 2-DOG $+0.5 \mathrm{mM} \mathrm{CN}{ }^{-}$ & $5.9 \pm 0.5$ \\
$10 \mathrm{mM}$ 2-DOG $+0.5 \mathrm{mM} \mathrm{CN}^{-}+10 \mu \mathrm{g} / \mathrm{ml}$ & \\
digitonin & $5.3 \pm 0.2$ \\
\hline
\end{tabular}

Cells at $5 \times 10^{7} / \mathrm{ml}$ were incubated at $37^{\circ} \mathrm{C}$ in $\mathrm{KRP}$ containing the additions as shown above. After $10 \mathrm{~min}$ the ATP was extracted and measured as is described in Methods. Results are the mean $\pm \mathrm{SD}$ of each sample done in triplicate.

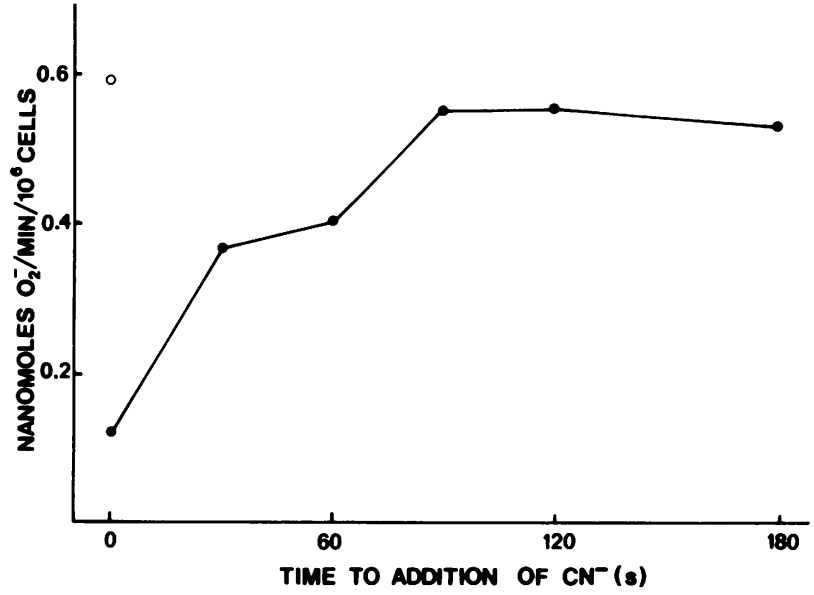

FIgURE 10 The effect of $\mathrm{CN}^{-}$on $\mathrm{O}_{2}^{-}$production by digitoninstimulated rabbit pulmonary alveolar macrophages. Macrophages at $5 \times 10^{6} / \mathrm{ml}$ were added to a standard assay for $\mathrm{O}_{2}^{-}$ production and at the times indicated on the abscissa, $\mathrm{CN}^{-}$ $(1 \mathrm{mM})$ was added and the linear rates of $\mathrm{O}_{2}^{-}$production were recorded $(0)$. The open circle represents the rate in the absence of added $\mathrm{CN}^{-}$.

mitochondrial oxidative phosphorylation (10). As can be seen in Fig. 10, $1 \mathrm{mM} \mathrm{CN}^{-}$completely inhibits the ability of these cells to generate $\mathrm{O}_{2}^{-}$when added at zero time. However, as the interval between the addition of cells and $\mathrm{CN}^{-}$is increased, progressively less inhibition is obtained. After $1.5 \mathrm{~min}$ no inhibition is seen. This corresponds to the activation time for maximum $\mathrm{O}_{2}^{-}$generation by these macrophages. Similar results were obtained with DNP. Incubating rabbit pulmonary alveolar macrophages for $15 \mathrm{~min}$ in $10 \mathrm{mM}$ 2-DOG resulted in no inhibition of digitonin-stimulated $\mathrm{O}_{2}^{-}$production.

Effect of energy metabolism on ingestion by granulocytes. We examined whether $\mathrm{CN}^{-}$by itself, or in the presence of 2-DOG would affect ingestion. Table IV shows that incubation of cells in $10 \mathrm{mM}$ 2-DOG for 15 min results in a $30 \%$ inhibition of ingestion and that $\mathrm{CN}^{-}$by itself does not inhibit ingestion. However, the addition of $\mathrm{CN}^{-}$to 2-DOG-treated cells results in almost complete inhibition of ingestion. To determine whether energy metabolism is essential for ingestion or for a step preceding it, $\mathrm{CN}^{-}$was added to cells incubated with 2-DOG at various times after mixing the cells with opsonized particles. $\mathrm{CN}^{-}$prevented any further ingestion whenever it was added to the system. Thus, although the enzyme generating $\mathrm{O}_{2}^{-}$is not affected by inhibition of ATP production, the system responsible for ingestion is affected by the inhibitors examined.

\section{DISCUSSION}

Digitonin stimulation of the oxidative burst in phagocytic cells mimicks stimulation by particles (11). We 
TABLE IV

Effect of 2-DOG and $\mathrm{CN}^{-}$on Ingestion of Opsonized

Endotoxin-Coated Phthalate Oil Particles

Containing Oil Red O

\begin{tabular}{ccc}
\hline & Oil red O & Inhibition \\
\hline & $m g / 10^{7}$ granulocytes/min & $\%$ \\
Control & 0.40 & - \\
$+\mathrm{CN}^{-}(1 \mathrm{mM})$ & 0.50 & \\
$2-\mathrm{DOG}(10 \mathrm{mM})$ & 0.32 & 30 \\
$+\mathrm{CN}^{-}(1 \mathrm{mM})$ & 0.05 & 91 \\
\hline
\end{tabular}

Cells $\left(4 \times 10^{7} / \mathrm{ml}\right)$ were incubated at $37^{\circ} \mathrm{C}$ in either $\mathrm{KRP}$ or $10 \mathrm{mM}$ 2-DOG. At $15 \mathrm{~min}, 0.8 \mathrm{ml}$ were removed and added to $0.2 \mathrm{ml}$ of Oil red $\mathrm{O}$ containing particles with and without $0.02 \mathrm{ml}$ of $0.05 \mathrm{M} \mathrm{NaCN}^{-}$and incubated at $37^{\circ} \mathrm{C}$ for $5 \mathrm{~min}$. The reaction was stopped with the addition of $10 \mathrm{ml}$ of icecold saline containing $1 \mathrm{mM} \mathrm{NEM}$, and washed twice with this solution. The dye was extracted with $1 \mathrm{ml}$ of dioxane and absorbance read at $520 \mathrm{~nm}$ against a dioxane blank.

have previously shown that the same $\mathrm{O}_{2}^{-}$generating system is activated by both this detergent and opsonized zymosan (1). The use of a continuous assay for $\mathrm{O}_{2}^{-}$production by digitonin-stimulated granulocytes allowed us to examine the effects of various compounds on both the activation of the generating system and the activity of the enzyme system itself.

NEM has been shown to inhibit the oxidative burst of phagocytosis $(6,7)$. NEM at concentrations between 0.1 and $1.0 \mathrm{mM}$ causes a progressively increasing inhibition of digitonin-induced $\mathrm{O}_{2}^{-}$generation by guinea pig granulocytes. We postulate that the mechanism of this inhibition is that NEM prevents the activation of the enzyme responsible for $\mathrm{O}_{2}^{-}$generation but has no effect on the enzyme activity as it exists in the cell. This is based on the observation that NEM inhibits $\mathrm{O}_{2}^{-}$production by digitonin-stimulated granulocytes only when added before complete activation of the enzyme and, in addition, prolongs the time necessary to activate the $\mathrm{O}_{2}^{-}$generating system.

Divalent cations play roles in both ingestion (12) and oxidative metabolism (11) by phagocytes. In digitonin-stimulated granulocytes, $\mathrm{Ca}^{++}$is essential and sufficient for maximal $\mathrm{O}_{2}^{-}$generation. $\mathrm{Mg}^{++}$, which by itself supports very little $\mathrm{O}_{2}^{-}$generation, decreases the amount of $\mathrm{Ca}^{++}$necessary to obtain full activity. $\mathrm{Ca}^{++}$ appears essential for activation but not for the activity itself. This is suggested by the ability of the $\mathrm{Ca}^{++}$-chelator EGTA to prevent digitonin-induced $\mathrm{O}_{2}^{-}$generation when added before, but not after, activation of the system. It is possible that $\mathrm{Ca}^{++}$transport occurs during the activation process and EGTA cannot bind the intracellular $\mathrm{Ca}^{++}$. The lack of effect of the $\mathrm{Ca}^{++}$ionophore, A23187, on activation argues against the possibility that $\mathrm{Ca}^{++}$transport is at least a rate limiting step. It has been previously reported that $\mathrm{O}_{2}^{-}$generation by cell-free particles does not require $\mathrm{Ca}^{++}$(13), and we have found no effect of EGTA on reduced pyridine nucleotidedependent $\mathrm{O}_{2}^{-}$generation by membrane fragments. ${ }^{2}$

The ability of granulocytes to generate $\mathrm{O}_{2}^{-}$when stimulated by digitonin is inhibited by incubation of the cells with 2-DOG. The inhibition is time- and concentration-dependent and correlates with the loss of ATP. ATP depletion is presumably due to both an inhibitory effect on glycolysis and to the formation of 2-DOG-6$\mathrm{PO}_{4}$ which cannot be further metabolized. Glucose prevents this inhibition by competing for membrane transport and phosphorylation. Mannose partially prevents this inhibition and ATP loss by competing for membrane transport. Various compounds presenting alternative energy sources could not prevent 2-DOG inhibition of $\mathrm{O}_{2}^{-}$production. These included: $(a)$ other six-carbon sugars, such as galactose and fructose; $(b) \mathrm{di}$ hydroxyacetone, which enters the glycolytic pathway at the triose level; $(c)$ adenosine and inosine, which enter through ribose phosphorylation (an ATP-independent process in erythrocytes [14]); and (d) pyruvate and succinate, which provide ATP through mitochondrial oxidative phosphorylation. These compounds also failed to prevent 2-DOG-induced ATP depletion. Combinations of these agents were equally ineffective. We conclude that either the granulocyte cannot utilize these substances as sources for ATP or 2-DOG may alter the cell to prevent these compounds from exerting their metabolic effects. Recently, Boxer et al. (15) have shown that 2-DOG inhibits phagocytosis of particles by guinea pig granulocytes with a concomitant decrease in intracellular ATP. They were able to reverse the ATP effect and some of the phagocytic effects by incubating the 2-DOG-treated cells with pyruvate for $60 \mathrm{~min}$. Our incubation conditions differed from theirs in that we used higher concentrations of 2-DOG and performed the assays after $15 \mathrm{~min}$ incubation.

$\mathrm{CN}^{-}$and DNP cause a greater amount of $\mathrm{O}_{2}^{-}$generation from digitonin-stimulated granulocytes. $\mathrm{CN}^{-}$may act in part by inhibiting myeloperoxidase. Myeloperoxidase-deficient granulocytes generate more $\mathrm{O}_{2}^{-}$than normal ones (16). However, $\mathrm{CN}^{-}$and DNP probably share a separate means of enhancing $\mathrm{O}_{2}^{-}$generation because DNP does not cause further stimulation of $\mathrm{CN}^{-}$stimulated cells, yet it is not known to affect myeloperoxidase. Jandl and Babior (17) have shown that stimulation of granulocytes with opsonized zymosan in the presence of either $\mathrm{CN}^{-}$or $\mathrm{N}_{3}^{-}$results in activation of more pyridine nucleotide oxidase in cellfree particles, and we (18) have shown that membrane fragments derived from digitonin-treated cells have a higher specific activity of this enzyme when cells are activated in the presence of glucose or $\mathrm{CN}^{-}$. These

\footnotetext{
${ }^{2}$ Cohen, H. J. Unpublished observations.
} 
results indicate that the presence of these metabolites affects the activation of more enzyme molecules rather than the intracellular concentration of the substrate(s) for the enzyme.

Baehner et al. (19) found that phagocytosis by granulocytes from a patient with phosphoglycerate kinase deficiency was sensitive to $\mathrm{CN}^{-}$. In these cells, energy formation from glycolysis is prevented so that only mitochondrial oxidative phosphorylation can serve as a source of ATP. It has also been shown that oligomycin, an inhibitor of mitochondrial electron transport, inhibits glucose oxidation in 2-DOG-treated granulocytes (20). In cells whose digitonin-induced stimulation of $\mathrm{O}_{2}^{-}$generation was only partially inhibited by 2-DOG, addition of $\mathrm{CN}^{-}$or DNP caused complete inhibition, indicating a role for mitochondrial ATP formation in activation of these cells. The inability of $\mathrm{CN}^{-}$ or DNP to prevent $\mathrm{O}_{2}^{-}$production when added after complete activation of the enzyme demonstrates that ATP formation is required only for activation of the enzyme and not for its continued activity. The ability of 2-DOG to increase the time necessary for activation shows that inhibition by 2 -DOG acts at least in part on the activation process.

Rabbit pulmonary alveolar macrophages, unlike most phagocytic cells, derive their energy from mitochondrial oxidative phosphorylation (10). In these cells, the addition of $\mathrm{CN}^{-}$, but not 2-DOG, inhibits digitonin-stimulated $\mathrm{O}_{2}^{-}$generation, but only when added before full activation.

Although the inhibition of $\mathrm{O}_{2}^{-}$generation by 2-DOG correlates with ATP depletion in the granulocyte, concomitant incubation of the cell with $\mathrm{CN}^{-}$which only slightly lowers the ATP content, completely inhibits $\mathrm{O}_{2}^{-}$production. This finding, together with the immediate effect of $\mathrm{CN}^{-}$on macrophage $\mathrm{O}_{2}^{-}$production, suggests that it is the ability to generate ATP and not the intracellular concentration of ATP that determines the rate and degree of activation, i.e., the process of activation is linked to ongoing energy formation.

Prolonged incubation of granulocytes with 2-DOG prevents ingestion of particles by the cells (21), and $\mathrm{CN}^{-}$by itself has no effect on this process (17). However, the addition of $\mathrm{CN}^{-}$to cells incubated for short periods of time with 2-DOG (so that only partial inhibition of ingestion occurs) results in almost complete inhibition of ingestion. Unlike its effect on $\mathrm{O}_{2}^{-}$, the addition of $\mathrm{CN}^{-}$at any time to 2-DOG-treated cells results in a cessation of ingestion.

Phagocytic cells from patients with chronic granulomatous disease cannot generate $\mathrm{O}_{2}^{-}$when stimulated by opsonized bacteria (22). Digitonin also fails to stimulate $\mathrm{O}_{2}^{-}$production by these cells. ${ }^{3}$ Chronic granulomatous disease can have both a sex-linked (23) and autosomal

\footnotetext{
${ }^{3}$ Cohen, H. J. Unpublished observations.
}

recessive (24) mode of inheritance. This suggests that defects in each of at least two factors can account for the same phenomenon. McPhail et al. (25) suggest that the sex-linked form of chronic granulomatous disease may result from an inability to activate a pyridine nucleotide oxidase. The effects of $\mathrm{NEM}, \mathrm{Ca}^{++}$, and energy metabolism on $\mathrm{O}_{2}^{-}$production indicate the complex nature of the conversion of a resting granulocyte to one that produces active oxygen metabolites. It is likely that more than a single molecular event is involved in this activation. Defects in any of these could result in a phagocytic cell devoid of the ability to generate bactericidal active oxygen metabolites.

\section{ACKNOWLEDGMENTS}

We would like to thank Dr. Thomas P. Stossel, Dr. Peter E. Newberger, and Dr. David G. Nathan for their support, encouragement, and helpful suggestions.

This work was supported by U. S. Public Health Service grant AI-08173-10.

\section{REFERENCES}

1. Cohen, H. J., and M. E. Chovaniec. 1978. Superoxide generation by digitonin-stimulated guinea pig granulocytes: A basis for a continuous assay for monitoring superoxide production and for the study of the activation of the generating system. J. Clin. Invest. 61: 1081-1087.

2. Stahelin, H., E. Suter, and M. L. Karnovsky. 1956. Studies on the interaction between phagocytes and tubercle bacilli. I. Observations on the metabolism of guinea pig leucocytes and the influence of phagocytosis.J. Exp. Med. 104: $121-136$.

3. Myrvik, Q. N., E. S. Leake, and B. Farris. 1961. Studies on pulmonary alveolar macrophages from the normal rabbit: A technique to procure them in a high state of purity. J. Immunol. 86: 128-132.

4. Kornberg, A. 1950. Reversible enzymatic synthesis of diphosphopyridine nucleotide and inorganic pyrophosphate. J. Biol. Chem. 182: 779-793.

5. Stossel, T. P., R. J. Mason, J. Hartwig, and M. Vaughan. 1972. Quantitative studies of phagocytosis by polymorphonuclear leukocytes: Use of emulsions to measure the initial rate of phagocytosis. J. Clin. Invest. 51: 615-624.

6. Sbarra, A. J., and M. L. Karnovsky. 1959. The biochemical basis of phagocytosis. I. Metabolic changes during the ingestion of particles by polymorphonuclear leukocytes. J. Biol. Chem. 234: 1355-1362.

7. Curnutte, J. T., and B. M. Babior. 1975. Effects of anaerobiosis and inhibitors on $\mathrm{O}_{2}^{-}$production by human granulocytes. Blood. 45: 851-861.

8. Stolc, V. 1975. Effects of calcium and lanthanum on iodine accumulation and release from human polymorphonuclear leukocytes. J. Reticuloendothel. Soc. 18: 213-220.

9. DeChatelet, L. R., L. C. McPhail, and P. S. Shirley. 1977. Effect of cyanide on NADPH oxidation by granules from human polymorphonuclear leukocytes. Blood. 49: 445454.

10. Simon, L. M., E. D. Robin, J. R. Philips, J. Acevedo, S. G. Axline, and J. Theodore. 1977. Enzymatic basis for bioenergetic differences of alveolar versus peritoneal macrophages and enzyme regulation by molecular $\mathrm{O}_{2}^{-}$. J. Clin. Invest. 59: 443-448.

11. Graham, R. C., Jr., M. J. Karnovsky, A. W. Shafer, E. A. 
Glass, and M. L. Karnovsky. 1967. Metabolic and morphological observations on the effect of surface-active agents on leukocytes. J. Cell Biol. 32: 629-647.

12. Stossel, T. P. 1973. Quantitative studies on phagocytosis. Kinetic effects of cations and heat-labile opsonins. J. Cell Biol. 58: 346-356.

13. Curnutte, J. T., M. L. Karnovsky, and B. M. Babior. 1976. Manganese-dependent NADPH oxidation by granulocyte particles. The role of superoxide and the nonphysiological nature of the manganese requirement. J. Clin. Invest. 57: 1059-1067.

14. Prankard, T. A. J., and K. I. Altman. 1954. A study of the metabolism of phosphorus in mammalian red cells. Biochem. J. 58: 622-633.

15. Boxer, L. A., R. L. Baehner, and J. Davis. 1977. The effect of 2-deoxyglucose on guinea pig polymorphonuclear leukocyte phagocytosis. J. Cell. Physiol. 91: 89-102.

16. Rosen, H., and S. J. Klebanoff. 1976. Chemiluminescence and superoxide production by myeloperoxidase deficient leukocytes. J. Clin. Invest. 58: 50-60.

17. Jandl, R. C., and B. M. Babior. 1976. Termination of the respiratory burst in human neutrophils. Am. Soc. Hematol. 19: 63. (Abstr.)

18. Cohen, J. H., and M. E. Chovaniec. 1977. The plasma membrane as the location for the granulocyte superoxide generating enzyme. Clin. Res. 25: 336A. (Abstr.)

19. Baehner, R. L., S. A. Feig, G. B. Segel, H. M. Anderson, and E. R. Jaffe. 1971. Metabolic, phagocytic and bactericidal properties of phosphoglycerate kinase deficient polymorphonuclear leukocytes. Blood. 38: 833. (Abstr.)

20. Kvarstein, B. 1970. Oxygen consumption during the initial stage of human leucocyte phagocytosis of polystyrene latex particles. Scand. J. Clin. Lab. Invest. 25: 337-348.

21. Boxer, L. A., R. L. Baehner, S. Richardson, and J. Davis. 1976. The effect of 2-deoxyglucose on guinea pig polymorphonuclear leukocyte phagocytosis. Clin. Res. 24: 304A. (Abstr.)

22. Curnutte, J. T., D. M. Whitten, and B. M. Babior. 1974 Defective superoxide production by granulocytes from patients with chronic granulomatous disease. N. Engl. J. Med. 290: 593-597.

23. Windhorst, D. B., B. Holmes, and R. A. Good. 1967. A newly defined $\mathrm{x}$-linked trait in man with demonstration of the Lyon effect in the carrier female. Lancet. I: 737 739.

24. Azimi, P. H., J. G. Bodenbender, R. L. Hintz, and S. B. Kontras. 1968. Chronic granulomatous disease in three female siblings. JAMA (J. Am. Med. Assoc.). 206: 28652870.

25. McPhail, L. C., L. R. DeChatelet, P. S. Shirley, C. Wilfert, R. B. Johnston, and C. E. McCall. 1977. Deficiency of NADPH oxidase activity in chronic granulomatous disease. J. Pediatr. 90: 213-217. 